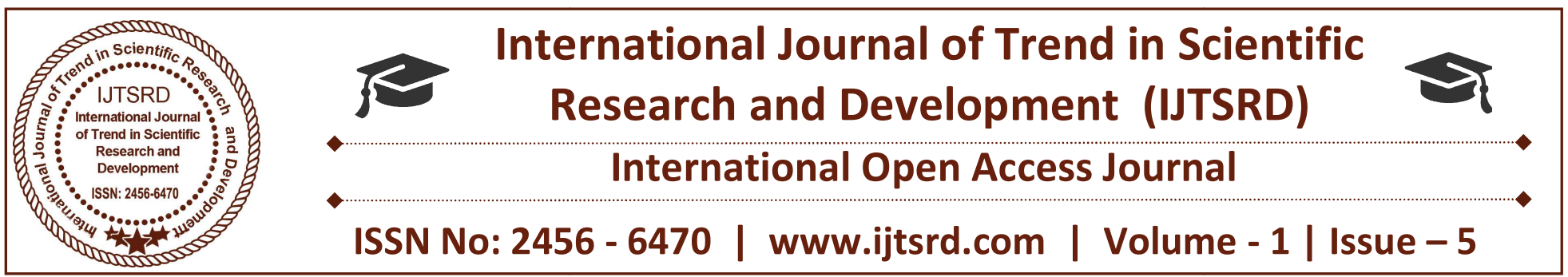

\title{
A Comparison of the use of Language in Ifeoma Okoye's Men Without Ears and Ayi Kwei Armah's the Beautyful Ones Are Not Yet Born
}

\author{
Unubi, Sunday Abraham \\ Department of Igala Language and Culture, \\ School of Languages, Kogi State College of \\ Education, PMB 1033, Ankpa, Nigeria
}

\author{
Ikani, Eneojo Friday \\ Department of Igala Language and Culture, \\ School of Languages, Kogi State College of \\ Education, PMB 1033, Ankpa, Nigeria
}

\begin{abstract}
This paper compares the use of language by both writers - Okoye and Armah to portray the social ills prevalent in their societies: Nigeria and Ghana. A comparative study of this kind is a useful dynamic and heuristic tool capable of throwing valuable light on the characteristic features of the two works compared (Firbas cited in Johansson (9), as paraphrased by us)). As a matter of fact, the researchers, through this paper, have brought to limelight the beauty of the two works in terms of the language use by the writers, and this has added more value to both works literarily and academically.
\end{abstract}

\section{Key word: language}

\section{INTRODUCTION}

Ifeoma Okoye and Ayi Kwei Armah use language as a tool to portray the corruption, pervasive moral, spiritual and physical decadence, unbridled quest for monetary and material gains, as well as lack of maintenance culture prevalent in their societies Nigeria and Ghana. In fact, the two writers point this out in one of their numerous words. According to Armah, life is so corrupt in Ghana that the good ones are imprisoned while the corrupt ones who are "cutting corners, eating the fruits of fraud" (95) and people like Abednego Yamoah who "who sells government petrol for himself (96) are cherished! In the word of Okoye, Nigeria is "...a country where money-bags were held above men of character and where means was a measure of virtue" (153). While Armah's language is vituperative, vitriolic and vulgar, that of Okoye is more of appealing. Both writers, no doubt, are punctilious and deliberate in their choice of language and use it to pursue a common cause; i.e., as a therapeutic tool meant to transform and effect changes in their decadent and dying societies. Below are some of the features in the language use by the two writers:

\section{Narration/Characterization}

Okoye, though a one-person narrator, the two novelists however use homodiegetic narration (protagonists) to tell their stories. Almost all the chapters of the two novels reveal that the writers properly use this to their advantage.

In the Beautyful Ones Are Not Yet Born, the narrator is the Teacher who tells the major stories and who as well listens, as a character, to the embittered remarks which Armah showers, not just on him alone but on all the corrupt inhabitants of Ghana. The Teacher narrates the story; he and the Man appear to be individual listeners too, listening to the problem of Ghana especially as caused by the profligate county politicians. This is reflected in the statement "after 
each telling of the story the teller would ask, as if he had been speaking to the air, why men should stand apart and disappoint themselves when people free to choose, choose what they want?" (80). Also, this reveals that the Teacher disapproves of corrupt materialism and ostentation.

Furthermore, apart from the Teacher, there are other characters like Koomson, Maanan, Yamoah, Zacharias, Amankwa, Aboliga, etc whose roles add aesthetic to the novel.

On the other hand, the homodiegetic characters in Ifeoma Okoye's Men Without Ears are Chigo and Father. They tell us more about the profligacy, getrich-quick syndrome and corruption of Uloko. In one of the instances, Father tells Chigo, "... Uloko has turned into a hard and scheming man who will do anything to get money and go to any lengths to show his wealth" (49). Moreover, Chigo declares, "... he had borrowed some money from me because he had none to pay up a debt..." (66). In terms of characterization, other characters like Anny, Adaego, Oyibo, Amaeze, Nweke and so on, play important roles that add beauty and flavour to the novel.

\section{Vulgarity/Scatology}

Anyone who has read Armah's The Beautyful Ones Are Not Yet Born knows that he explores vulgar, obscene, indecent and unconventional language to expose rust and rottenness in his Ghanian society. However, the irony is that the writer's vulgarity rather adds to the artistic and aesthetic quality of the novel. This language is uniquely and deliberately crafted this way to serve as an electroconvulsive tool. In other words, it is intended to shock the readers to calculatingly draw their consideration to the dreadfully shocking and repulsive things and behaviours like corruption, materialism moral degeneration, filth and the pervasive moral, spiritual and physical deterioration in the society in order to effect a change. The fact here is that Armah depicts corruption to discuss the theme of corruption. Some of the examples of this are:

"You bloody fucking son of a bitch!"(6), "Uncircumcised baboon" (9), "Moron of a frog" (9) "...to shit in their people's faces..." (82), “...seen their arseholes and drawn away in disgusted laughter?" (82). Here the writer's use of insults belies his resentment, and what can be described as his deep contempt for black politicians, who after using the people to gain political power, turn against them and exploit them.

Others are: "Your mother's rotten cunt!" (9), "VAGINA SWEET" (106), "Young juicy vaginas waiting for him in some hired place paid by the government" (86). It may appear that the writer is portraying his blatant disrespect for the carnal parts of the human body, but this is not the case. It is rather to expose and severely criticize the politicians' wanton sexual abuse and corrupting of young girls. Also, the consequence of this raw, inelegant and shocking language is, therefore, to expose the pervasive and heightened moral decadence in the political corridors and the entire fabric of Ghana.

On her part, Ifeoma Okoye in Men Without Ears does not use vulgar language but humane, elegant and polite language to expose corruption in her country (Nigeria), and appeals for change of attitude. However, both writers have a common denominator, that is, to effect changes in their societies. Though Okoye uses humane language, it is pungent and perspicacious enough to achieve this purpose.

\section{Ellipsis}

Both writers adroitly make use of ellipsis to add flavour to their works. On his part, Armah appears to have made use of marked ellipsis in his novel to show that corrupt practices or statements stick to the mouth, and as such, they are sometimes avoided completely, hence, the use of the dots to represent the unvoiced words, phrases and ideas. For example, Oyo's mother says "thought... (138). Here, the narrator states that in the middle of what she wants to say, something seems to have struck her mind and she stops. Other examples are: "the food is fine but the drink... (115), "But when man is alone here all through the night..." (15), "...serving our own selves..." (86), "...in the end, we are our own enslavers first" (86), "It is about the Ahead..."(135).

On her part, Okoye's examples of the use of ellipsis are as follows: "Wash a pig, oil a pig..." (60), "It pains me greatly to see a well-brought up son change overnight into a..." (49), "Yes..." (137). 


\section{Analepsis and Prolepsis}

Another heuristic device used by Armah in the portrayal of corruption in the novel is analepsis and prolepsis. These terms are preferred to the terms of flashback and flash-forward which they stand to represent. In this sense, Ghana has been metaphorically reflected as an 'old man-child' as represented by the story told by Aboliga, the frog. According to the story, the picture is of the "manchild in its grey old age, completely old in everything save for the smallness of its size" (63).

Ghana is a newly independent country but deep in corruption, just like the man-child looks "irretrievably old, far more thoroughly decayed than any other ordinary old man" (63). On the other hand, Armah's implantation of the character and the quality of the Man- a man standing different in the face of corrupt and dissident society, is proleptic of the hope of a better society which will be born in future.

On her part, this language device is not very visible in Okoye's Men Without Ears. However, a semblance of analepsis (flashback) is Chigo's desire to go back to Tanzania "I wish I could go back to Tanzania" (125).

\section{Repetitions}

No doubt, both writers use repetition for the sake of emphasis. The writers in their novels repeat some words, phrases or clauses to catch the attention of their readers. They include:

Ayi Kwei Armah: "And Jesus wept, Aha Jesus wept" (4), "Preferably Maanan,... Preferably Maanan... 'preferably Maanan” (87), “...Money swine, Money swine" (110).

$>$ Ifeoma Okoye: "You don't seem to understand the impropriety of the thing you want me to do for you. You don't seem to understand that what you want me to do for you could ruin my career" (124), "I can't" “I just can't. It's not done" (124).

\section{Titles}

The two novelists use titles in their novels. These titles exude some feeling of pomposity and importance in the characters involved. By contrast, the titles in Ayi Kwei Armah's The Beautyful Ones Are Not Yet Born are more of official and professional while that of Ifeoma Okoye's Men Without Ears are more or less traditional and hyperbolic. Some of the examples are as follows:

Ayi Kwei Armah: "His Excellency", "Minister Plenipotentiary", "Hero of Socialist Labour" (56), "Professor", "The Attorney General" (133).

Ifeoma Okoye: "Young Millionaire", Madam Cash", "Money Maker", "Madam True Money" (24), etc.

\section{Pidgin English}

Both writers use pidgin artistically to add aesthetic quality to their novels. Some of the instances of pidgin in the novel include:

Ayi kwei Armah: "Aaah, contrey broke oo, countrey no broke oo, we dey inside" (82), "...mah contery people no happy, sah" (83), "MONEY SWEET PASS ALL", "WHO BORN FOOL", "SOCIALISM MAKE I CHOP", "YOU BROKE NOT SO?", "JAILMAN CHOP FREE" (106).

Ifeoma Okoye: “... you de travel, sir?... you don get boarding pass, sir?... I fit help you get one, sir... just give me fifty naira, sir... you go see. Maybe you new for this place. Nobody fit give you boarding pass unless you give am money" (2).

\section{Code-Mixing}

Both authors bring their native language into English. This does not mean lack of adequate vocabulary on their parts but aptly and artfully done with a view to spicing up the language. Some of them include:

Ayi kwei Armah: "kenkey" (8), “juju” (18), "kente" (28), "Da" (107), "obuasi" (108), "fufu" (110).

$>$ Ifeoma Okoye: "agbada" 910), "buba"(20), "Obi" (32), "Igwe" (37), "ofala" (42), “Oga" (106).

\section{The Use of Symbols}

Both writers use symbols to add colour and aesthetic to their works. In The Beautyful Ones Are Not Yet Born, one bus appears at the beginning of the novel and another at the end. The buses are essentially the same, in spite of the second one looking deceptively bright and new. The new bus bears the motto: "The 
Beautyful Ones Are Not Yet Born" (183). The misspelling of the word 'beautiful' symbolically seems to warn the Ghanian masses not to expect so much from it. In addition, the drivers and conductors of these buses are more subtle in their corrupt dealings. The buses symbolize the Ghanian populace or nation while the drivers and conductors symbolize the entire leadership of the nation. Furthermore, the nakedness of the Teacher symbolizes the death of Ghana until the 'beautyful' ones who will redeem the country from its state of dilapidation and ruin are born. In the word of the novel, "There is salvation of some kind, of course, said the naked man, but only within the cycle of our damnation itself" (56).

In Men Without Ears, the statement: "The setting sun...casting a beam on his face" (132) is symbolic. The sun symbolizes Chigo's father while its setting symbolizes his death.

\section{The Use of Oxymoron}

Both authors use this literary device of placing incongruous or contradictory terms side by side in order to spice up their writing. In Armah, we find examples of such as: "waking sleeper" (15), walking in his sleep", "sleepwalker" (33) and (34). In Okoye, the phrase: 'thrive in disorderliness' (1) is an example.

\section{CONCLUSION}

It is pertinent to point out once and again that both writers have a similar theme: to expose corruption, oppression, moral degeneration as well as the unbridled quest or desire for money and material gains, and to effect a desirable change in their societies - Nigeria and Ghana. This they have decided to do artfully and uniquely through the use of language. Indeed, words have the potentiality to heal, save, kill, make and mar. An English proverb says: "words cut keener than knives" (Adedimeji, 18).

\section{WORKS CITED}

1) Adedimeji, Mahfouz. Word Structure in English. Department of English, Faculty of Arts, University of Ilorin, Nigeria. 2005. Print.

2) Armah, Ayi Kwei. The Beautiful Ones are Not Yet Born. Heinemann Publishers (pty) Limited, 1986. Print.

3) Chukwuloo, Chukwueloka Christian. Portrayal of Corruption as Narrative in The Beautyful Ones Are Not Yet Born. Volume 5. African Research

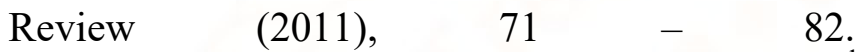
http://dx.doi.org/10.4314/ accessed on $22^{\text {nd }}$ August, 2017.

4) Johansson, Stig. Contrastive Analysis and Learner Language: A Corpus-based Approach. University of Oslo, 2008. Print.

5) Kakraba, Alexander Dakubo. Ayi Kwei Armah's Vulgar Language in The Beautiful Ones are Not Yet Born, a Therapeutic Tool. Maxwell Scientific Organization, 2011. Print.

6) Okoye, Ifeoma. Men Without Ears. Mageb Printers Ltd, 1984. Print. 